\title{
REVIEW
}

\section{Can faulty antennae increase adiposity? The link between cilia proteins and obesity}

\author{
Piya Sen Gupta, Natalia V Prodromou and J Paul Chapple \\ Barts and the London School of Medicine and Dentistry, William Harvey Research Institute, Centre for Endocrinology, Queen Mary University of London, \\ Charterhouse Square, London EC1M 6BQ, UK \\ (Correspondence should be addressed to J P Chapple; Email: j.p.chapple@qmul.ac.uk)
}

\begin{abstract}
Primary cilia are sensory organelles that protrude from the surface of most mammalian cell types. In humans and mice, mutations in proteins required for normal cilia function have been identified as causing a class of disorders with overlapping phenotypes known as ciliopathies. Recent evidence has linked obesity in ciliopathies to both the regulation of energy
\end{abstract}

homeostasis in the hypothalamus and to adipogenesis. This article considers the role of cilia in these processes and whether cilia dysfunction may be relevant to more common forms of obesity.

Journal of Endocrinology (2009) 203, 327-336

\section{Introduction}

In 2003, it was recognized that mutations in proteins essential for normal cilia function underlie Bardet-Biedl syndrome (BBS, Ansley et al. 2003; for details on the function of BBS proteins see Box 1). Subsequently, cilia dysfunction has been linked to further rare congenital multisystem disorders that have been termed ciliopathies (Table 1). These syndromes have some phenotypic overlap, for example retinal degeneration and kidney disease are common features, although penetrance is variable. The clinical features of two of these conditions, BBS and Alström's syndrome (ALS; Badano et al. 2006), incorporate a subset of endocrine phenotypes and in particular obesity. This review focuses on the potential cellular mechanisms by which disruption of ciliary protein function may lead to obesity. That variance in common obesity linked genes may impact upon cilia function is also considered.

\section{What are primary cilia?}

Primary cilia are small organelles, $\sim 2-5 \mu \mathrm{m}$ in length (up to $30 \mu \mathrm{m}$ in some cell types) that extend from the surface of the majority of mammalian cells (Fig. 1; Praetorius \& Spring 2005). For example, they are found throughout the brain including the hypothalamus (Bishop et al. 2007). They function as sensory antennae and are involved in the regulation of a number of key cellular signaling pathways, including hedgehog signaling (Pazour \& Witman 2003, Singla \& Reiter 2006). Cilia consist of an axoneme and a basal body. The basal body is derived from a mother centriole that migrates to the plasma membrane after cell division. Structurally, the axoneme consists of nine microtubule doublets, originating from basal body triplet microtubules, covered by a ciliary membrane that is continuous with the plasma membrane. The formation of the axoneme from the basal body is dependent on the process of intraflagellar transport (IFT; Fig. 2). Axonemal synthesis occurs at the end distal to the basal body and IFT is necessary for structural proteins to be transported to this location. IFT is bidirectional with kinesin motor driven anterograde transport and dynein motor driven retrograde transport. The entry of proteins into the ciliary compartment and membrane is regulated and there is evidence for a protein quality control machinery at the basal body (Stephan et al. 2007).

Primary cilia are structurally different from motile cilia, for example those of the respiratory epithelium responsible for mucociliary clearance, as they normally lack a central microtubule pair and other structural features including radial spokes, inner dynein arms, and outer dynein arms. Thus, primary cilia have a $9+0$ microtubule organization and motile cilia have a $9+2$ composition. Generally, $9+0$ cilia are not motile, though the nodal cilia, essential for the left and right axis development in early mammalian embryogenesis, are an exception (Nonaka et al. 1998). Likewise, not all 9+2 


\section{Box 1 Function of BBS proteins and ALMS1}

Mutations in 12 genes have been identified as causative for BBS, with multiple protein-protein interactions occurring between the encoded proteins. A heptameric BBS protein complex containing BBS1, BBS2, BBS4, BBS5, BBS7, BBS8, and BBS9 has been identified (Nachury et al. 2007). This complex, known as the BBSome, localizes to both centriolar satellites (electron dense granules localized around the centrosome) and to the ciliary membrane. Depletion of BBSome proteins does not appear to affect centriolar satellites, but does cause a large reduction in ciliation. Other proteins were also reported to be associated with the BBSome including Rabin8, a guanosyl exchange factor (GEF) for the small GTPase Rab8. Rab8 functions in targeting post-golgi vesicles to polarized areas of the plasma membrane (Ang et al. 2003) and may promote docking and fusion of exocytotic vesicles to the base of the ciliary membrane (Nachury et al. 2007). Expression of a dominant negative, GDPlocked, Rab8 inhibits ciliation in cultured cells and has been shown to cause rhodopsin to accumulate at the base of the connecting cilium and cause cell death in Xenopus laevis photoreceptors (Moritz et al. 2001).

A function for BBS proteins in intracellular transport is further suggested by the identification of an ADPribosylation factor-like (ARL) protein, ARL6 as BBS3 (Chiang et al. 2004). ARL proteins, along with ADPribosylation factor proteins, form a group of regulatory GTPases that function in the regulation of both microtubule dynamics and vesicle traffic (Kahn et al. 2005). The other BBS proteins are BBS11/TRIM32, which is an E3 ubiquitin ligase, and BBS6, BBS10 and BBS12 which have homology to the type II chaperonin family of molecular chaperones (Chiang et al. 2006, Stoetzel et al. 2007). Thus, it is plausible that BBS proteins that are not components of the BBSome may play a regulatory role for this complex (Nachury et al. 2007), such as mediating assembly/disassembly.

Importantly, BBS proteins do not function solely at cilia. Knockdown of Bbs proteins in zebrafish causes a defect in retrograde transport along microtubules of melanosomes (Yen et al. 2006), tissue-specific lysosome-related organelles in which melanins are synthesized and stored (Raposo \& Marks 2007). Furthermore, BBS4 is an adapter protein of the $\mathrm{p} 150^{\text {glued }}$ subunit of the dynein-dynactin microtubule motor complex recruiting pericentriolar material-1 and associated cargos to centriolar satellites (Kim et al. 2004). BBS4 knockdown disrupts both centrosomal and basal body function leading to a disruption of cellular microtubule organization (Kim et al. 2004).

ALMS1 is an extremely large protein (4169 amino acids) that localizes with centrosomes and basal bodies (Hearn et al. 2005). It contains 34 imperfect repeats of a 44 amino acid sequence and a short polyglutamine tract. Its knockdown in mice causes stunted cilia in kidney epithelial cells (Li et al. 2007). Details of ALMS1 function at the molecular level remain to be elucidated.

cilia are considered motile, e.g. the kinocilium of cochlear hair cells (Sobkowicz et al. 1995, Fliegauf et al. 2007).

Cilia have cell-type-specific functions that depend on the particular signaling machineries localized to them. For example, in olfactory sensory neurons, odorant receptors localize at the ciliary membrane, while in the primary cilia of kidney epithelial cells polycystin-2 (a transient receptor potential ion channel) functions as a mechanoreceptor detecting urine flow (Nauli et al. 2003). In some cells types, cilia are morphologically adapted to their specific function. This can clearly be seen in the photoreceptor outer segment which is part of a modified axoneme that is specialized for efficient light detection and phototransduction.

\section{Cilia localization of receptors}

The multiple components of ciliopathy phenotypes appear to result from disruption of signaling pathways that are cell-typespecific. It is therefore important to consider which cell surface receptors are present at the ciliary membrane. For example, for GPCRs several cilia localization motifs have been identified. Rhodopsin has a C-terminal VxPx motif that binds the small GTPase ARF4, regulating assembly of a ciliary targeting complex at the trans-golgi network (Mazelova et al. 2009). A hydrophobic and basic residue motif, C-terminal to the last transmembrane segment of GPCRs, have also been identified as a ciliary localization motif (Dwyer et al. 2001). This motif is required for the cilia localization of the hedgehog signaling pathway by the smoothened protein (Corbit et al. 2005). The motif is found in somatostatin receptor 3 (SSTR3) and serotonin receptor 6 (HTR6), but is also in other, non-cilia localized, somatostatin and serotonin receptors. This suggests it may be necessary, yet not sufficient, for cilia localization (Berbari et al. 2008a). Subsequently, based upon the finding that a conserved sequence in the third intracellular loop of SSTR 3 and HTR6 is required for their ciliary localization, the consensus sequence Ala X [Ser/Ala] X Glu (where $\mathrm{X}=$ any residue) was also derived as a cilia localization motif (Berbari et al. 2008a). 

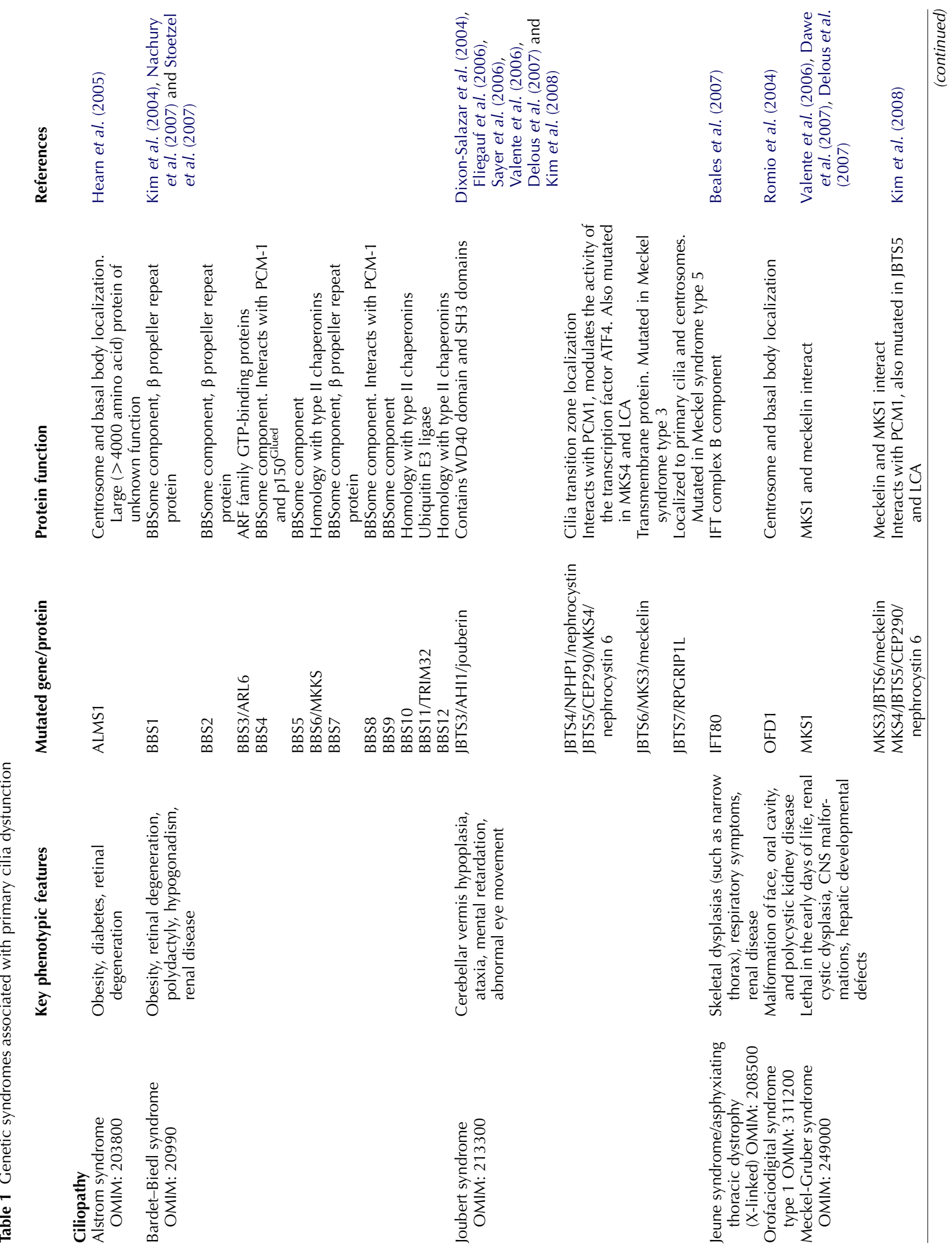


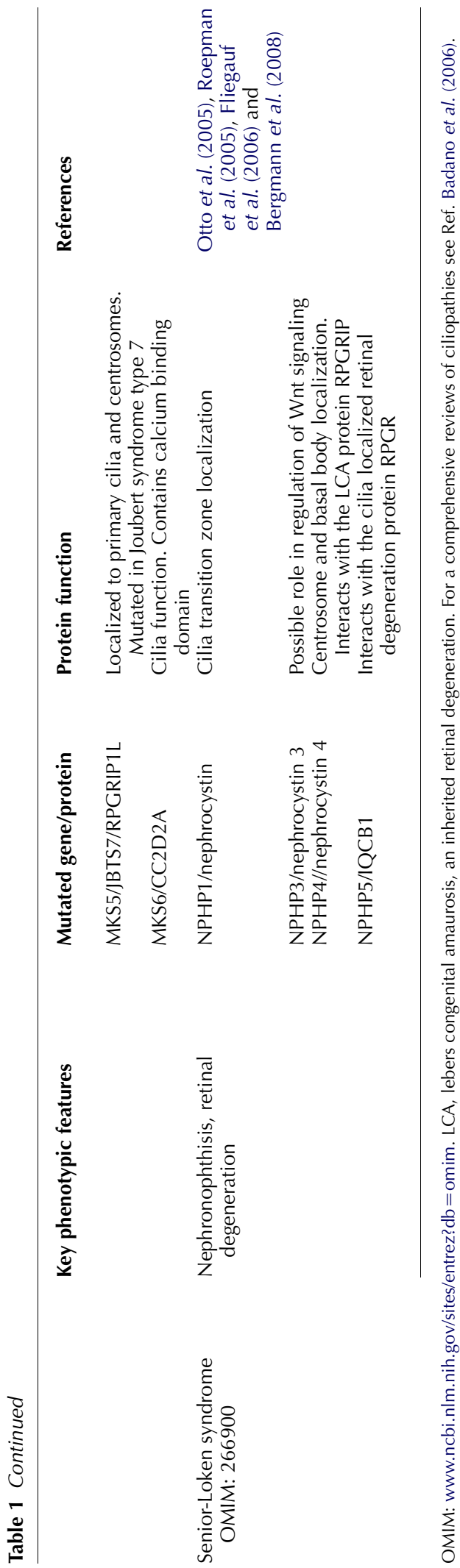

Journal of Endocrinology (2009) 203, 327-336

\section{Obesity in BBS and ALS}

Obesity may be considered an energy balance disorder in which energy intake exceeds energy expenditure, resulting in storage of the excess energy in adipose tissue (Box 2). Nearly all ALS patients have been reported to be obese while more than $70 \%$ of BBS patients are reported to be overweight (Beales et al. 1999, Marshall et al. 2005). In both syndromes, truncal obesity develops in childhood and has been suggested to be linked to hyperphagia. In ALS, endocrine phenotypes of hyperinsulinemia, insulin resistance, and type 2 diabetes mellitus are common, while diabetes is also a secondary feature of BBS (Beales et al. 1999, Marshall et al. 2005).

Fat Aussie mice that have a spontaneous mutation in the ortholog of the gene responsible for ALS in humans, have a normal birth weight but exhibit hyperphagia and become severely obese. These mice also develop insulin resistance, diabetes, with morphological changes in pancreatic islets, and features of metabolic syndrome (Arsov et al. 2006). BBS knockout mice are again obese and hyperphagic, and furthermore, compared with wild-type littermates, they exhibit reduced locomotor activity (Rahmouni et al. 2008).

\section{Primary cilia play a role in satiety signaling in the hypothalamus}

These mouse models and others have been used to elucidate the pathophysiological pathway by which the mutations in cilia associated proteins result in obesity. IFT has been targeted using conditional tamoxifen-inducible knockouts of the heterotrimeric kinesin-2 motor component gene Kif3a and the IFT gene $T g 737$ (also known as Ift88/polaris; Davenport et al. 2007). Conditional knockouts were necessary because disruption of IFT is embryonic lethal. After four weeks of tamoxifen administration both Kif3a and $\operatorname{Tg} 737$ knockout mice were significantly fatter than untreated controls and went on to develop obesity with elevated plasma levels of glucose, insulin, and leptin. Pair feeding studies revealed this weight gain was due to hyperphagia. Unlike BBS knockout mice reduced locomotor activity was not reported for Kif3a and $\mathrm{Tg} 737$ conditional knockouts. Thus, abnormal regulation of feeding behavior was strongly implicated in causing the phenotype observed in these IFT impaired mice. To further investigate this, Davenport et al. created central nervous system (CNS) specific knockouts by crossing the cilia mutant mice with synapsin-1-cre mice. The obesity phenotype was recapitulated in this model and, subsequently, pro-opiomelanocortin (POMC) expressing neurons of the hypothalamus were identified as the affected neuronal population, by specifically disrupting Kif3a using a POMC-cre deletor line. Cilia were lost from the POMC expressing neurons in the knockout 

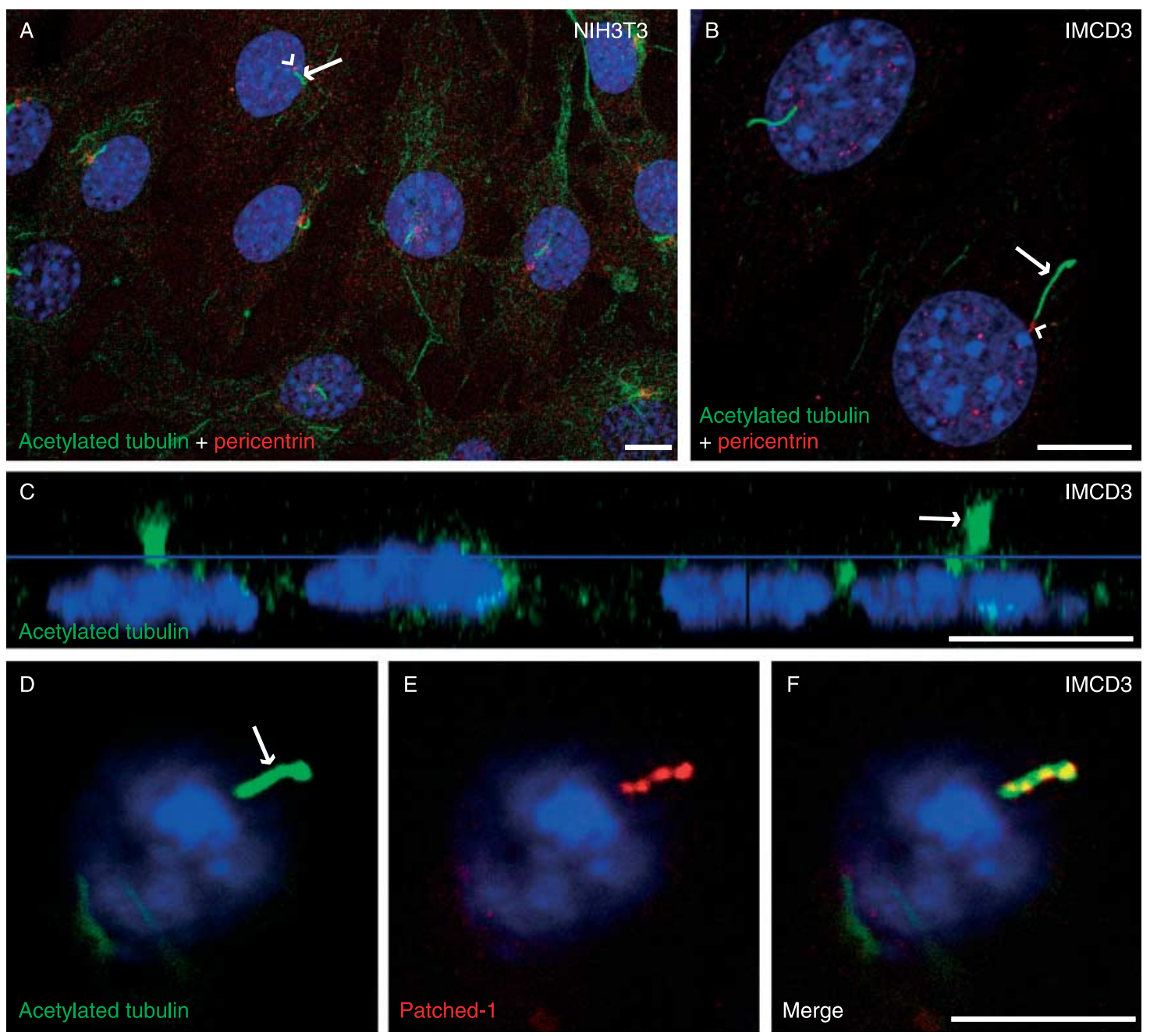

Figure 1 Primary cilia protrude from the surface of mammalian cells and localize components of key signal transduction pathways. Confocal microscope images of primary cilia in NIH3T3 (A) and IMCD3 cells (B-F). Ciliary axonemes and basal bodies were detected with antibodies against acetylated tubulin and pericentrin respectively. (C) Z-section. (D-F) The sonic hedgehog signaling pathway protein patched-1 localizes to primary cilia. Nuclei are stained with DAPI (blue). Scale bar $=10 \mu \mathrm{m}$.

mice, leading the authors to conclude neuronal cilia function in a pathway regulating the satiety response (Davenport et al. 2007).

\section{Leptin receptor signaling is impaired in BBS}

Rahmouni et al. (2008) showed that BBS mice have high levels of plasma leptin and increased leptin resistance. The possibility that BBS mutations may inhibit transport of leptin across the blood-brain barrier was excluded by i.c.v. administration of leptin. Hypothalamic leptin acts to alter expression of the downstream energy homeostasis neuropeptides POMC, agouti-related protein (AGRP) and neuropeptide Y (NPY). In $\mathrm{Bbs}^{-1-}$ mice, Pomc mRNA levels are reduced and levels of the other neuropeptides unchanged, compared with $\mathrm{Bbs}^{+/+}$mice (Rahmouni et al. 2008). As with IFT mutant mice, these findings point towards BBS mice having a defect in POMC neurons that accounts for the obesity phenotype.

As hyperleptinemia and leptin resistance may be secondary to obesity, the same group went on to examine the effects of exogenous leptin administrations in $\mathrm{Bbs}^{-/-}$mice where calorific restriction had been used to normalize weight and serum leptin levels to that of control animals (Seo et al. 2009). In these $B b s^{-1-}$ mice, with normal weight and endogenous leptin levels, exogenous leptin did not cause weight loss or reduced food intake. In this study, Seo et al. (2009) also demonstrated that targeting melanocortin receptors (MCRs), by i.c.v. administration of agonist, resulted in reduced food intake and weight in BBS mice. 


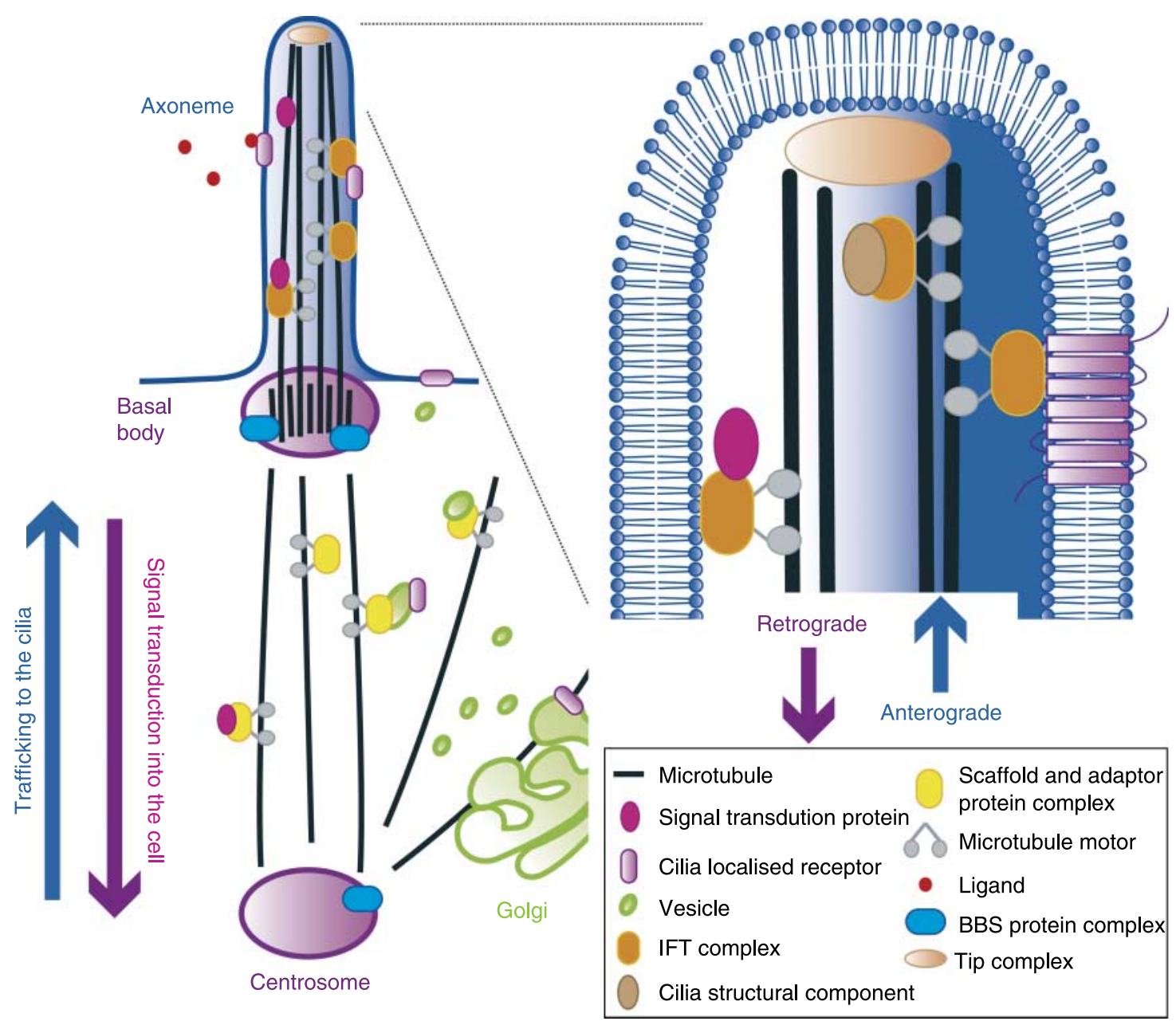

Figure 2 Schematic representation of primary cilia, showing microtubule-dependent trafficking to and from the basal body, as well as IFT of cargos within the axoneme.

In the hypothalamus, binding of leptin to the leptin receptor isoform $\mathrm{LRb}$ causes phosphorylation of signal transducer and activator of transcription-3 (STAT3), which then activates POMC transcription (Bates et al. 2003). In BBS mice normalized for weight and serum leptin levels, exogenous leptin administration has a reduced ability to activate this signaling pathway, as evidenced by reduced STAT3 phosphorylation (Seo et al. 2009). LRb has also been shown to interact with BBS1 by co-immunoprecipitation. BBS1 was not reported to precipitate other leptin receptor isoforms. Furthermore, LRb does not appear to interact directly with other BBS proteins (Seo et al. 2009), although BBS1 does form a stable complex with them (see Box 1; Nachury et al. 2007). Knockdown of BBS proteins in cultured cells exogenously expressing LRb has been shown to cause a change in localization of the receptor that is suggestive of a defect in trafficking from the golgi (Seo et al. 2009).

$\mathrm{LRb}$ has not been reported to be localized to the cilia of POMC neurons, although it has been reported to be enriched in the ciliary membranes of olfactory sensory neurons (Baly et al. 2007). Therefore, both a failure of $\mathrm{LRb}$ transport from the golgi, possible to the basal body, and/or transport within the ciliary membrane may cause obesity.

Interestingly, melanin-concentrating hormone receptor 1 (MCHR1) contains the Ala X [Ser/Ala] X Glu motif and has been localized to primary cilia. This localization is disrupted in BBS mice (Berbari et al. 2008b). This is relevant because $\mathrm{MCH}$ is a hypothalamic neuropeptide, involved in the regulation of energy homeostasis, that is believed to act downstream of leptin (Shimada et al. 1998, Ludwig et al. 2001, Chen et al. 2002, Segal-Lieberman et al. 2003). However, disruption of MCHR1 results in obesity resistance in mice (Chen et al. 2002), while mice lacking $\mathrm{MCH}$ are lean and hypophagic (Shimada et al. 1998). It is unknown if other GPCRs, more directly involved in the hypothalamic regulation of energy homeostasis, such as MC3R and MC4R, are ever associated with cilia. 


\section{Box 2 Obesity and regulation of energy homeo- stasis}

Energy homeostasis is regulated by multiple peripheral signals that are integrated in the CNS and in particular the hypothalamus (for recent reviews see: (Coll et al. 2007, Crowley 2008, Woods \& D'Alessio 2008)). Monogenic causes of human obesity have highlighted the critical role of the leptin-melanocortin system in the control of food intake. Leptin is a peptide, secreted by adipose tissue, which normally circulates at levels proportional to body fat. Leptin attenuates appetite and increases thermogenesis in mice, with its deficiency resulting in obesity in mice and humans (Zhang et al. 1994, Montague et al. 1997). Leptin crosses the blood-brain barrier and, at the hypothalamic arcuate nucleus, modulates neuropeptide expression in cocaine and amphetamine regulated/POMC neurons and AGRP/NPY neurons. POMC and AGRP neurons also project to a number of second order neurons, which express neuropeptides involved in regulating energy balance. The expression of POMC is increased in response to leptin and decreased in leptin deficiency and fasting states. POMC is cleaved into peptides, including $\alpha$ - and $\beta-\mathrm{MSH}$, which are ligands for the MCRs, downstream regulators of energy homeostasis.

\section{Cilia and adipocytes}

Adipocytes originate from mesenchymal precursor cells that differentiate into preadipocytes. Preadipocytes may remain dormant or undergo further adipogenesis to become adipocytes. The master adipogenic regulator of this process is the transcription factor peroxisome proliferator-activated receptor $\gamma$ (PPARG). Wnt signaling inhibits PPARG and CCAAT-enhancer-binding proteins (CEBPA, -B), which are also adipogenic (Ross et al. 2000). Hedgehog signaling also affects PPARG and CEBPA causing a reduction in expression of these proteins in 3T3-L1 adipogenic cells (Suh et al. 2006). Thus, both hedgehog and Wnt signaling are anti-adipogenic (Cousin et al. 2007, King et al. 2008, Christodoulides et al. 2009). In mouse models, reduced white fat mass has been observed in mice where the inhibitor of smoothened, patched, is truncated and hedgehog signaling is activated ( $\mathrm{Li}$ et al. 2008), while expression of $W n t 10 b$, under the control of an adiposespecific promoter (Fabp 4), resulted in transgenic mice that had a $\sim 50 \%$ reduction in total body fat and resistance to expansion of adipose tissue when fed a high fat diet (Longo et al. 2004). As cilia function/IFT is essential for normal hedgehog signaling in mammalian cells (Huangfu et al. 2003, Haycraft et al. 2005,
Huangfu \& Anderson 2005), and is also implicated in the modulation of canonical, $\beta$-catenin-dependent, Wnt signaling (Gerdes et al. 2007, Corbit et al. 2008), it is possible that the obesity phenotype of ciliopathies may also be linked to disruption of these pathways.

A recent study from Marion et al. (2009) has reported that cilia are present on differentiating human white preadipocytes, yet are absent from both proliferating preadipocytes and mature adipocytes. These differentiating preadipocyte cilia have a $9+2$ microtubule organization and localize hedgehog and Wnt signaling components at the axoneme. Furthermore, reduction of BBS10 and BBS12 expression was shown to reduce preadipocyte cilia incidence and affects key regulators of adipogenesis (Marion et al. 2009). In particular, levels of PPARG and activated glycogen synthase kinase $3 \beta$ (GSK3B) were reported to be elevated in adipocytes where BBS10 and BBS12 were knocked down, indicating promotion of adipogenic pathways (Marion et al. 2009). In canonical Wnt signaling, GSK3 is inactivated resulting in dephosphorylation of $\beta$-catenin and its nuclear accumulation, while in hedgehog signaling inhibition of GSK3 promotes stabilization of the Gli2 and Gli3 transcription factors leading to transcription of target genes. The Marion et al. (2009) study also reports that adipocytes derived from BBS patients had higher triglyceride content and increased levels of leptin secretion compared with controls.

Furthermore, the ALS protein, ALMS1, has been reported to be expressed at high levels in preadipocyte 3T3-L1 cells, with expression reducing in preadipocyte to adipocyte differentiation (Romano et al. 2008).

In contrast to disruption of the hypothalamic regulation of energy balance, defects in normal adipocyte differentiation have not been strongly implicated in the development of obesity. However, Marion et al. (2009) highlighted a recent study which reported that adipose tissue uses lipokines to regulate systemic metabolic homeostasis (Cao et al. 2008) and went on to suggest that adipogenesis may directly participate in the pathogenesis of obesity. For BBS, this would imply obesity results from two different routes.

Interestingly, RAB23, which is a negative regulator of hedgehog signaling, has been identified as mutated in Carpenter's syndrome, a congenital disorder which has obesity as part of the phenotype (Jenkins et al. 2007). RAB23 functions in regulation of vesicular transport, possible in cilia, (Huangfu \& Anderson 2006). However, the obesity phenotype observed in Carpenter's syndrome may not be directly related to a defect in the hedgehog signaling pathway, but could represent a consequence of impaired vesicular transport of another, unknown, protein.

\section{$B B S$ gene variants associated with common obesity}

Heterozygous carriers of BBS mutations have been reported to be more likely to be obese than control individuals (Croft et al. 1995). Single nucleotide polymorphisms (SNPs) have 
subsequently been identified in BBS genes and non-coding variants in $B B S 2, B B S 4$, and $B B S 6$, but not $B B S 1$, suggested to be associated with obesity in a French-Caucasian population (Benzinou et al. 2006). Interestingly, the SNPs in BBS4 and BBS6 were shown to be associated with childhood and adult obesity, while an intronic SNP in BBS2 was only associated with adult obesity. Another study in a Danish population failed to link variants in BBS6 to obesity (Andersen et al. 2005), however, this study examined coding polymorphisms. These coding changes were not associated with obesity in the French-Caucasian population either (Benzinou et al. 2006). The importance of variance in BBS genes, towards common obesity, is unclear as genome-wide association studies (GWAS) have not reported association.

\section{Possible association of the ciliary gene RPGRIP1L with obesity?}

GWAS have identified common variants in the fat mass and obesity-associated (FTO) gene that predispose towards elevated body mass index (BMI) and obesity (Dina et al. 2007, Frayling et al. 2007, Scuteri et al. 2007, Thorleifsson et al. 2009). SNPs at the FTO locus are the variants most strongly associated with high BMI and weight in people of European ancestry. The region of FTO that contains obesity associated SNPs is up to $47 \mathrm{~kb}$ and contains parts of intron 1 and 2, as well as exon 2, of this gene. Intriguingly, another gene, RPGRIP1L (also known as FTM) which is cilia associated, lies in the opposite orientation and has its transcriptional start $\sim 3.4 \mathrm{~kb}$ upstream of $F T O$, leading to the possibility that either FTO, RPGRIP1L or both could account for the association of variance in this genetic interval with obesity (Frayling et al. 2007, Stratigopoulos et al. 2008). However, obesity is not a feature of Joubert syndrome (cerebello-oculo-renal syndrome), an autosomal recessive ciliopathy caused by mutations in RPGRIP (Delous et al. 2007). Moreover, in FTO deleted mice, where FTM expression is unaltered, a significant reduction in body weight, adipose tissue and adipocyte size has been reported (Fischer et al. 2009).

\section{Conclusions}

There is strong evidence for defects in the hypothalamic regulation of energy homeostasis, in particular regulation of feeding, in mouse models where cilia protein function has been deleted. Loss of cilia protein function most likely affects leptin receptor signaling. There is also evidence that differentiating preadipocytes are ciliated, BBS proteins are needed for cilia maintenance in these cells, and loss of cilia may release repression of adipogenesis by hedgehog and Wnt signaling. However, it remains unclear if cilia mediated defects in adipocyte differentiation are directly linked to the development of obesity. Importantly, some cilia proteins also function in processes not directly related to cilia (see Box 1). For example, specific cilia proteins play a role in intracellular transport (for e.g. vesicular transport along microtubules), beyond the cilium. Thus, it cannot categorically be concluded that cilia function is directly required for normal maintenance of body weight. Furthermore, although cilia proteins can be mechanistically linked to obesity in genetic syndromes and it is also unclear if cilia/cilia proteins are important in common forms of obesity.

\section{Declaration of interest}

The authors declare that there is no conflict of interest that could be perceived as prejudicing the impartiality of the research reported.

\section{Funding}

Cilia research in JPC's laboratory is supported by BBSRC grant BBE0098241. PSG holds a National Institute for Health Research Academic Clinical Fellowship.

\section{Acknowledgements}

We would like to thank Dr Peter King for his useful comments on the text and Abid Shoaib for help with preparation of the manuscript.

\section{References}

Andersen KL, Echwald SM, Larsen LH, Hamid YH, Glumer C, Jorgensen T, Borch-Johnsen K, Andersen T, Sorensen TI, Hansen T et al. 2005 Variation of the McKusick-Kaufman gene and studies of relationships with common forms of obesity. Journal of Clinical Endocrinology and Metabolism 90 225-230.

Ang AL, Folsch H, Koivisto UM, Pypaert M \& Mellman I 2003 The Rab8 GTPase selectively regulates AP-1B-dependent basolateral transport in polarized Madin-Darby canine kidney cells. Journal of Cell Biology 163 339-350.

Ansley SJ, Badano JL, Blacque OE, Hill J, Hoskins BE, Leitch CC, Kim JC, Ross AJ, Eichers ER, Teslovich TM et al. 2003 Basal body dysfunction is a likely cause of pleiotropic Bardet-Biedl syndrome. Nature 425 628-633.

Arsov T, Silva DG, O'Bryan MK, Sainsbury A, Lee NJ, Kennedy C, Manji SS, Nelms K, Liu C, Vinuesa CG et al. 2006 Fat aussie - a new Alstrom syndrome mouse showing a critical role for ALMS1 in obesity, diabetes, and spermatogenesis. Molecular Endocrinology 20 1610-1622.

Badano JL, Mitsuma N, Beales PL \& Katsanis N 2006 The ciliopathies: an emerging class of human genetic disorders. Annual Review of Genomics and Human Genetics 7 125-148.

Baly C, Aioun J, Badonnel K, Lacroix MC, Durieux D, Schlegel C, Salesse R \& Caillol M 2007 Leptin and its receptors are present in the rat olfactory mucosa and modulated by the nutritional status. Brain Research $\mathbf{1 1 2 9}$ $130-141$.

Bates SH, Stearns WH, Dundon TA, Schubert M, Tso AW, Wang Y, Banks AS, Lavery HJ, Haq AK, Maratos-Flier E et al. 2003 STAT3 signalling is required for leptin regulation of energy balance but not reproduction. Nature $\mathbf{4 2 1} 856-859$.

Beales PL, Elcioglu N, Woolf AS, Parker D \& Flinter FA 1999 New criteria for improved diagnosis of Bardet-Biedl syndrome: results of a population survey. Journal of Medical Genetics 36 437-446. 
Beales PL, Bland E, Tobin JL, Bacchelli C, Tuysuz B, Hill J, Rix S, Pearson CG, Kai M, Hartley J et al. 2007 IFT80, which encodes a conserved intraflagellar transport protein, is mutated in Jeune asphyxiating thoracic dystrophy. Nature Genetics 39 727-729.

Benzinou M, Walley A, Lobbens S, Charles MA, Jouret B, Fumeron F, Balkau B, Meyre D \& Froguel P 2006 Bardet-Biedl syndrome gene variants are associated with both childhood and adult common obesity in French Caucasians. Diabetes 55 2876-2882.

Berbari NF, Johnson AD, Lewis JS, Askwith CC \& Mykytyn K 2008a Identification of ciliary localization sequences within the third intracellular loop of G protein-coupled receptors. Molecular Biology of the Cell 19 1540-1547.

Berbari NF, Lewis JS, Bishop GA, Askwith CC \& Mykytyn K $2008 b$ BardetBiedl syndrome proteins are required for the localization of $\mathrm{G}$ proteincoupled receptors to primary cilia. PNAS 105 4242-4246.

Bergmann C, Fliegauf M, Bruchle NO, Frank V, Olbrich H, Kirschner J, Schermer B, Schmedding I, Kispert A, Kranzlin B et al. 2008 Loss of nephrocystin-3 function can cause embryonic lethality, Meckel-Gruberlike syndrome, situs inversus, and renal-hepatic-pancreatic dysplasia. American Journal of Human Genetics 82 959-970.

Bishop GA, Berbari NF, Lewis J \& Mykytyn K 2007 Type III adenylyl cyclase localizes to primary cilia throughout the adult mouse brain. Journal of Comparative Neurology 505 562-571.

Cao H, Gerhold K, Mayers JR, Wiest MM, Watkins SM \& Hotamisligil GS 2008 Identification of a lipokine, a lipid hormone linking adipose tissue to systemic metabolism. Cell 134 933-944.

Chen Y, Hu C, Hsu CK, Zhang Q, Bi C, Asnicar M, Hsiung HM, Fox N, Slieker LJ, Yang DD et al. 2002 Targeted disruption of the melaninconcentrating hormone receptor-1 results in hyperphagia and resistance to diet-induced obesity. Endocrinology 143 2469-2477.

Chiang AP, Nishimura D, Searby C, Elbedour K, Carmi R, Ferguson AL, Secrist J, Braun T, Casavant T, Stone EM et al. 2004 Comparative genomic analysis identifies an ADP-ribosylation factor-like gene as the cause of Bardet-Biedl syndrome (BBS3). American Journal of Human Genetics 75 475-484.

Chiang AP, Beck JS, Yen HJ, Tayeh MK, Scheetz TE, Swiderski RE, Nishimura DY, Braun TA, Kim KY, Huang J et al. 2006 Homozygosity mapping with SNP arrays identifies TRIM32, an E3 ubiquitin ligase, as a Bardet-Biedl syndrome gene (BBS11). PNAS 103 6287-6292.

Christodoulides C, Lagathu C, Sethi JK \& Vidal-Puig A 2009 Adipogenesis and WNT signalling. Trends in Endocrinology and Metabolism 20 16-24.

Coll AP, Farooqi IS \& O'Rahilly S 2007 The hormonal control of food intake. Cell 129 251-262.

Corbit KC, Aanstad P, Singla V, Norman AR, Stainier DY \& Reiter JF 2005 Vertebrate smoothened functions at the primary cilium. Nature $\mathbf{4 3 7}$ 1018-1021.

Corbit KC, Shyer AE, Dowdle WE, Gaulden J, Singla V, Chen MH, Chuang PT \& Reiter JF 2008 Kif3a constrains beta-catenin-dependent Wnt signalling through dual ciliary and non-ciliary mechanisms. Nature Cell Biology 10 70-76.

Cousin W, Fontaine C, Dani C \& Peraldi P 2007 Hedgehog and adipogenesis: fat and fiction. Biochimie 89 1447-1453.

Croft JB, Morrell D, Chase CL \& Swift M 1995 Obesity in heterozygous carriers of the gene for the Bardet-Biedl syndrome. American Journal of Medical Genetics 55 12-15.

Crowley VE 2008 Overview of human obesity and central mechanisms regulating energy homeostasis. Annals of Clinical Biochemistry 45 245255.

Davenport JR, Watts AJ, Roper VC, Croyle MJ, van GT, Wyss JM, Nagy TR, Kesterson RA \& Yoder BK 2007 Disruption of intraflagellar transport in adult mice leads to obesity and slow-onset cystic kidney disease. Current Biology 17 1586-1594.

Dawe HR, Smith UM, Cullinane AR, Gerrelli D, Cox P, Badano JL, Blair-Reid S, Sriram N, Katsanis N, Attie-Bitach T et al. 2007

The Meckel-Gruber Syndrome proteins MKS1 and meckelin interact and are required for primary cilium formation. Human Molecular Genetics $16173-186$.
Delous M, Baala L, Salomon R, Laclef C, Vierkotten J, Tory K, Golzio C, Lacoste T, Besse L, Ozilou C et al. 2007 The ciliary gene RPGRIP1L is mutated in cerebello-oculo-renal syndrome ( Joubert syndrome type B) and Meckel syndrome. Nature Genetics 39 875-881.

Dina C, Meyre D, Gallina S, Durand E, Korner A, Jacobson P, Carlsson LM, Kiess W, Vatin V, Lecoeur C et al. 2007 Variation in FTO contributes to childhood obesity and severe adult obesity. Nature Genetics 39 724-726.

Dixon-Salazar T, Silhavy JL, Marsh SE, Louie CM, Scott LC, Gururaj A, Al Gazali L, Al Tawari AA, Kayserili H, Sztriha L et al. 2004 Mutations in the AHI1 gene, encoding jouberin, cause Joubert syndrome with cortical polymicrogyria. American Journal of Human Genetics 75 979-987.

Dwyer ND, Adler CE, Crump JG, L'Etoile ND \& Bargmann CI 2001 Polarized dendritic transport and the AP-1 mu1 clathrin adaptor UNC-101 localize odorant receptors to olfactory cilia. Neuron 31 277-287.

Fischer J, Koch L, Emmerling C, Vierkotten J, Peters T, Bruning JC \& Ruther U 2009 Inactivation of the Fto gene protects from obesity. Nature 458 894-898.

Fliegauf M, Horvath J, von Schnakenburg C, Olbrich H, Muller D, Thumfart J, Schermer B, Pazour GJ, Neumann HP, Zentgraf H et al. 2006 Nephrocystin specifically localizes to the transition zone of renal and respiratory cilia and photoreceptor connecting cilia. Journal of the American Society of Nephrology 17 2424-2433.

Fliegauf M, Benzing T \& Omran H 2007 When cilia go bad: cilia defects and ciliopathies. Nature Reviews. Molecular and Cellular Biology 8 880-893.

Frayling TM, Timpson NJ, Weedon MN, Zeggini E, Freathy RM, Lindgren CM, Perry JR, Elliott KS, Lango H, Rayner NW et al. 2007 A common variant in the FTO gene is associated with body mass index and predisposes to childhood and adult obesity. Science 316 889-894.

Gerdes JM, Liu Y, Zaghloul NA, Leitch CC, Lawson SS, Kato M, Beachy PA, Beales PL, DeMartino GN, Fisher S et al. 2007 Disruption of the basal body compromises proteasomal function and perturbs intracellular Wnt response. Nature Genetics 39 1350-1360.

Haycraft CJ, Banizs B, ydin-Son Y, Zhang Q, Michaud EJ \& Yoder BK 2005 Gli2 and Gli3 localize to cilia and require the intraflagellar transport protein polaris for processing and function. PLoS Genetics 1 e 53.

Hearn T, Spalluto C, Phillips VJ, Renforth GL, Copin N, Hanley NA \& Wilson DI 2005 Subcellular localization of ALMS1 supports involvement of centrosome and basal body dysfunction in the pathogenesis of obesity, insulin resistance, and type 2 diabetes. Diabetes 54 1581-1587.

Huangfu D \& Anderson KV 2005 Cilia and hedgehog responsiveness in the mouse. PNAS 102 11325-11330.

Huangfu D \& Anderson KV 2006 Signaling from Smo to Ci/Gli: conservation and divergence of hedgehog pathways from Drosophila to vertebrates. Development 133 3-14.

Huangfu D, Liu A, Rakeman AS, Murcia NS, Niswander L \& Anderson KV 2003 Hedgehog signalling in the mouse requires intraflagellar transport proteins. Nature 426 83-87.

Jenkins D, Seelow D, Jehee FS, Perlyn CA, Alonso LG, Bueno DF, Donnai D, Josifova D, Mathijssen IM, Morton JE et al. 2007 RAB23 mutations in Carpenter syndrome imply an unexpected role for hedgehog signaling in cranial-suture development and obesity. American Journal of Human Genetics $801162-1170$.

Kahn RA, Volpicelli-Daley L, Bowzard B, Shrivastava-Ranjan P, Li Y, Zhou C \& Cunningham L 2005 Arf family GTPases: roles in membrane traffic and microtubule dynamics. Biochemical Society Transactions $\mathbf{3 3}$ $1269-1272$.

Kim JC, Badano JL, Sibold S, Esmail MA, Hill J, Hoskins BE, Leitch CC, Venner K, Ansley SJ, Ross AJ et al. 2004 The Bardet-Biedl protein BBS4 targets cargo to the pericentriolar region and is required for microtubule anchoring and cell cycle progression. Nature Genetics $36462-470$.

Kim J, Krishnaswami SR \& Gleeson JG 2008 CEP290 interacts with the centriolar satellite component PCM-1 and is required for Rab8 localisation to the primary cilium. Human Molecular Genetics 17 3796-3805.

King PJ, Guasti L \& Laufer E 2008 Hedgehog signalling in endocrine development and disease. Journal of Endocrinology 198 439-450.

Li G, Vega R, Nelms K, Gekakis N, Goodnow C, McNamara P, Wu H, Hong NA \& Glynne R 2007 A role for Alstrom syndrome protein, alms1, in kidney ciliogenesis and cellular quiescence. PLoS Genetics 3 e8. 
Li Z, Zhang H, Denhard LA, Liu LH, Zhou H \& Lan ZJ 2008 Reduced white fat mass in adult mice bearing a truncated patched 1 . International Journal of Biological Sciences 4 29-36.

Longo KA, Wright WS, Kang S, Gerin I, Chiang SH, Lucas PC, Opp MR \& MacDougald OA $2004 \mathrm{Wnt} 10 \mathrm{~b}$ inhibits development of white and brown adipose tissues. Journal of Biological Chemistry 279 35503-35509.

Ludwig DS, Tritos NA, Mastaitis JW, Kulkarni R, Kokkotou E, Elmquist J, Lowell B, Flier JS \& Maratos-Flier E 2001 Melanin-concentrating hormone overexpression in transgenic mice leads to obesity and insulin resistance. Journal of Clinical Investigation 107 379-386.

Marion V, Stoetzel C, Schlicht D, Messaddeq N, Koch M, Flori E, Danse JM, Mandel JL \& Dollfus H 2009 Transient ciliogenesis involving Bardet-Biedl syndrome proteins is a fundamental characteristic of adipogenic differentiation. PNAS 106 1820-1825.

Marshall JD, Bronson RT, Collin GB, Nordstrom AD, Maffei P, Paisey RB, Carey C, Macdermott S, Russell-Eggitt I, Shea SE et al. 2005 New Alstrom syndrome phenotypes based on the evaluation of 182 cases. Archives of Internal Medicine 165 675-683.

Mazelova J, Astuto-Gribble L, Inoue H, Tam BM, Schonteich E, Prekeris R, Moritz OL, Randazzo PA \& Deretic D 2009 Ciliary targeting motif VxPx directs assembly of a trafficking module through Arf4. EMBO Journal 28 183-192.

Montague CT, Farooqi IS, Whitehead JP, Soos MA, Rau H, Wareham NJ, Sewter CP, Digby JE, Mohammed SN, Hurst JA et al. 1997 Congenital leptin deficiency is associated with severe early-onset obesity in humans. Nature 387 903-908.

Moritz OL, Tam BM, Hurd LL, Peranen J, Deretic D \& Papermaster DS 2001 Mutant rab8 impairs docking and fusion of rhodopsin-bearing post-Golgi membranes and causes cell death of transgenic Xenopus rods. Molecular Biology of the Cell 12 2341-2351.

Nachury MV, Loktev AV, Zhang Q, Westlake CJ, Peranen J, Merdes A, Slusarski DC, Scheller RH, Bazan JF, Sheffield VC et al. 2007 A core complex of BBS proteins cooperates with the GTPase Rab8 to promote ciliary membrane biogenesis. Cell 129 1201-1213

Nauli SM, Alenghat FJ, Luo Y, Williams E, Vassilev P, Li X, Elia AE, Lu W, Brown EM, Quinn SJ et al. 2003 Polycystins 1 and 2 mediate mechanosensation in the primary cilium of kidney cells. Nature Genetics 33 129-137.

Nonaka S, Tanaka Y, Okada Y, Takeda S, Harada A, Kanai Y, Kido M \& Hirokawa N 1998 Randomization of left-right asymmetry due to loss of nodal cilia generating leftward flow of extraembryonic fluid in mice lacking KIF3B motor protein. Cell 95 829-837.

Otto EA, Loeys B, Khanna H, Hellemans J, Sudbrak R, Fan S, Muerb U, O’Toole JF, Helou J, Attanasio M et al. 2005 Nephrocystin-5, a ciliary IQ domain protein, is mutated in Senior-Loken syndrome and interacts with RPGR and calmodulin. Nature Genetics 37 282-288.

Pazour GJ \& Witman GB 2003 The vertebrate primary cilium is a sensory organelle. Current Opinion in Cell Biology 15 105-110.

Praetorius HA \& Spring KR 2005 A physiological view of the primary cilium. Annual Review of Physiology 67 515-529.

Rahmouni K, Fath MA, Seo S, Thedens DR, Berry CJ, Weiss R, Nishimura DY \& Sheffield VC 2008 Leptin resistance contributes to obesity and hypertension in mouse models of Bardet-Biedl syndrome. Journal of Clinical Investigation 118 1458-1467.

Raposo G \& Marks MS 2007 Melanosomes - dark organelles enlighten endosomal membrane transport. Nature Reviews. Molecular and Cellular Biology 8 786-797.

Roepman R, Letteboer SJ, Arts HH, van Beersum SE, Lu X, Krieger E, Ferreira PA \& Cremers FP 2005 Interaction of nephrocystin-4 and RPGRIP1 is disrupted by nephronophthisis or Leber congenital amaurosis-associated mutations. PNAS 102 18520-18525.

Romano S, Milan G, Veronese C, Collin GB, Marshall JD, Centobene C, Favaretto F, Dal Pra C, Scarda A, Leandri S et al. 2008 Regulation of Alstrom syndrome gene expression during adipogenesis and its relationship with fat cell insulin sensitivity. International Journal of Molecular Medicine 21 731-736.

Romio L, Fry AM, Winyard PJ, Malcolm S \& Woolf AS 2004 OFD1 is a centrosomal/basal body protein expressed during mesenchymal-epithelial transition in human nephrogenesis. Journal of the American Society of Nephrology 15 2556-2568.
Ross SE, Hemati N, Longo KA, Bennett CN, Lucas PC, Erickson RL \& MacDougald OA 2000 Inhibition of adipogenesis by Wnt signaling. Science 289 950-953.

Sayer JA, Otto EA, O’Toole JF, Nurnberg G, Kennedy MA, Becker C, Hennies HC, Helou J, Attanasio M, Fausett BV et al. 2006 The centrosomal protein nephrocystin-6 is mutated in Joubert syndrome and activates transcription factor ATF4. Nature Genetics 38 674-681.

Scuteri A, Sanna S, Chen WM, Uda M, Albai G, Strait J, Najjar S, Nagaraja R, Orru M, Usala G et al. 2007 Genome-wide association scan shows genetic variants in the FTO gene are associated with obesity-related traits. PLoS Genetics 3 e115.

Segal-Lieberman G, Bradley RL, Kokkotou E, Carlson M, Trombly DJ, Wang X, Bates S, Myers MG Jr, Flier JS \& Maratos-Flier E 2003 Melaninconcentrating hormone is a critical mediator of the leptin-deficient phenotype. PNAS 100 10085-10090.

Seo S, Guo DF, Bugge K, Morgan DA, Rahmouni K \& Sheffield VC 2009 Requirement of Bardet-Biedl syndrome proteins for leptin receptor signaling. Human Molecular Genetics 18 1323-1331.

Shimada M, Tritos NA, Lowell BB, Flier JS \& Maratos-Flier E 1998 Mice lacking melanin-concentrating hormone are hypophagic and lean. Nature 396 670-674.

Singla V \& Reiter JF 2006 The primary cilium as the cell's antenna: signaling at a sensory organelle. Science 313 629-633.

Sobkowicz HM, Slapnick SM \& August BK 1995 The kinocilium of auditory hair cells and evidence for its morphogenetic role during the regeneration of stereocilia and cuticular plates. Journal of Neurocytology 24 633-653.

Stephan A, Vaughan S, Shaw MK, Gull K \& McKean PG 2007 An essential quality control mechanism at the eukaryotic basal body prior to intraflagellar transport. Trafic 8 1323-1330.

Stoetzel C, Muller J, Laurier V, Davis EE, Zaghloul NA, Vicaire S, Jacquelin C, Plewniak F, Leitch CC, Sarda P et al. 2007 Identification of a novel BBS gene (BBS12) highlights the major role of a vertebrate-specific branch of chaperonin-related proteins in Bardet-Biedl syndrome. American Journal of Human Genetics 80 1-11.

Stratigopoulos G, Padilla SL, LeDuc CA, Watson E, Hattersley AT, McCarthy MI, Zeltser LM, Chung WK \& Leibel RL 2008 Regulation of Fto/Ftm gene expression in mice and humans. American Journal of Physiology. Regulatory, Integrative and Comparative Physiology 294 R1185-R1196.

Suh JM, Gao X, McKay J, McKay R, Salo Z \& Graff JM 2006 Hedgehog signaling plays a conserved role in inhibiting fat formation. Cell Metabolism 3 25-34.

Thorleifsson G, Walters GB, Gudbjartsson DF, Steinthorsdottir V, Sulem P, Helgadottir A, Styrkarsdottir U, Gretarsdottir S, Thorlacius S, Jonsdottir I et al. 2009 Genome-wide association yields new sequence variants at seven loci that associate with measures of obesity. Nature Genetics $\mathbf{4 1}$ $18-24$.

Valente EM, Silhavy JL, Brancati F, Barrano G, Krishnaswami SR, Castori M, Lancaster MA, Boltshauser E, Boccone L, Al Gazali L et al. 2006 Mutations in CEP290, which encodes a centrosomal protein, cause pleiotropic forms of Joubert syndrome. Nature Genetics 38 623-625.

Woods SC \& D'Alessio DA 2008 Central control of body weight and appetite. Journal of Clinical Endocrinology and Metabolism 93 S37-S50.

Yen HJ, Tayeh MK, Mullins RF, Stone EM, Sheffield VC \& Slusarski DC 2006 Bardet-Biedl syndrome genes are important in retrograde intracellular trafficking and Kupffer's vesicle cilia function. Human Molecular Genetics 15 667-677.

Zhang Y, Proenca R, Maffei M, Barone M, Leopold L \& Friedman JM 1994 Positional cloning of the mouse obese gene and its human homologue. Nature 372 425-432.

Received in final form 7 May 2009

Accepted 21 May 2009

Made available online as an Accepted Preprint 21 May 2009 